\title{
Hvað veldur vanda á lyflækningasviði?
}

\section{Ingibjörg Kristjánsdóttir}

deildarlæknir á Iyflækningasviði og viðskiptafræð̌ingur

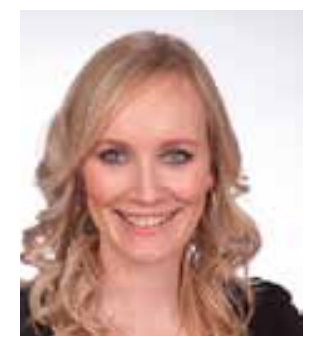

ingibjorgk@gmail.com

Allir pekkja söguna um litlu negrastrákana tíu par sem einn og einn datt úr lestinni par til enginn var eftir. Pað er neyðarástand á lyflækningasviði Landspítala, aðallega vegna mannfæðar. En af hverju hafa æ fleiri deildarlæknar helst úr lestinni? Er pað vegna óánægju með vinnuaðstöðu, lélegrar kennslu og pjálfunar, lágra launa, óánægju með stjórnunaraðferðir? Eða er ástæðan sambland af öllu ofangreindu?

Fyrir um fjórum árum hóf ég kandídatsár mitt á Landspítala og horfði björtum augum til framtíðar. Stefnan var sett á lyflækningar og sótt um í framhaldsprógrammi Landspítalans í almennum lyflækningum. Раð komust ekki allir að sem vildu; stöðurnar voru eftirsóttar vegna góðrar kennslu og pjálfunar, sanngirni í vaktabyrði, góðrar handleiðslu peirra sérfræðinga sem par vinna og góðs vinnuanda. Ég varð himinlifandi pegar ég fékk skilaboð um að hafa fengið stöðu og hlakkaði til næstu priggja ára par sem ég myndi slást í hóp deildarlækna á lyflækningasviði. En hver varð raunin, bæði hvað varðar menntun og starfið sjálft?

Á lyflækningasviði eru skilgreind 25 stöðugildi fyrir deildarlækna og pegar ég byrjaði voru 24 við vinnu. En svo fór samfella í dagvinnu minnkandi og par með okkar helsta lærdómstækifæri, pað er stofugangurinn. Par sem fullmannað teymi fer yfir tilfelli og ræðir um mögulegar orsakir, meðferðir og fleira og lærir af peim. Fullmannað teymi er sérfræðingur, deildar- læknir, kandídat og 1-2 læknanemar. Hins vegar hefur raunin verið sú að fækkað hefur um 1-2 lækna í hverju teymi. Pví hefur tími til kennslu á stofugangi minnkað og lærdómstækifærum um leið. Petta er ein helsta ástæða pess að fleiri og fleiri hafa helst úr lestinni, pví dettur mér aftur í hug sagan um litlu negrastrákana.

Sumarið 2013 voru eftir 14 deildarlæknar á lyflækningasviði svo samningur var gerður við yfirmenn um að ganga nær eingöngu vaktir pað sumarið með loforði um breytingar um haustið. Pví var dagvinnu bjargað með læknanemum er voru að stíga sín fyrstu skref í vinnu á háskólasjúkrahúsi með ábyrgð og álagi sem engan veginn samrýmdist peirra reynslu né menntun. Vaktabyrði síðastliðin ár hefur aukist og vissulega er margt að læra af vöktum í byrjun en svo kemur að pví að pær verða reglubundin vinnuskylda par sem aðaláhersla er lögð á að koma sem flestum sjúklingum gegnum kerfið á sem stystum tíma. Í erlendum prógrömmum pykir eðlilegt að vaktir séu um 1-2 mánuðir á ári en hér eru teknar vaktir eftir pörf spítalans.

Í september 2013 voru eftir 10 deildarlæknar og peim mun fækka enn par sem tveir hverfa frá í október. Hafa sérfræðingar og deildarlæknar á lyflækningasviði varað við pessari próun að minnsta kosti síðastliðin tvö ár. Nefndir hafa verið stofnaðar til að skoða vinnu- og vaktafyrirkomulag deildar- og aðstoðarlækna á lyflækningasviði sem hafa skilað inn góðum hugmyndum að úrbótum. En pví miður hafa stjórnendur spítalans ekki hlustað, heldur virðist sem vinnu pessara nefnda hafi verðið stungið undir stól til pessa.

Pann 1. september síðastliðinn var sett í gang neyðaráætlun og voru pá settar af stað misgóðar breytingar. Teymum var fækkað úr 12 í 6 fullmönnuð kennsluteymi sem skyldu mest hafa 14 sjúklinga hvert. Parna er tvennt jákvætt: að pau teymi sem hafa deildarlækna séu fullskipuð og að skil- greint sé hversu marga sjúklinga eitt teymi getur sinnt. Önnur breyting sem kom fram í neyðaráætluninni var að leggja niður vaktalínu deildarlæknis í Fossvogi og setja pess í stað tvo kandídata á vakt. Pannig er vaktabyrði kandídata aukin og peir hafðir einir í húsi að næturlagi án stuðnings sér reyndari læknis. Pví er verið að endurtaka sömu mistökin og gerð voru með deildarlækna og eru meðal annars orsök pess að við erum í pessum vanda.

Starfspróun er nauðsynleg fyrir lækna og ekki er pað uppörvandi fyrir deildarlækni sem brátt hverfur til sérnáms að horfa á störfum hlaðna sérfræðinga sinna deildarlæknavinnu til viðbótar. •að er ekki til að hvetja unga sérfræðilækna til að koma erlendis frá til vinnu á lyflækningasviði og hefur pað verið raunin að færri og færri sérfræðilæknar sækja „heim“ til vinnu, prátt fyrir hina miklu og pekktu ættjarðarást.

Mesti auður hvers fyrirtækis er gott starfsfólk. Mikilvægasta hlutverk hvers stjórnanda er að hlusta á starfsmenn sína og hlúa að peim. Ég tel af framansögðu að stjórnendur spítalans hafi hvorki hlustað á starfsmenn sína né brugðist við viðvörunum um vinnuumhverfi deildarlækna á lyflækningasviði síðastliðin tvö ár. Рað er byrjað að vinna að úrbótum sem ekki er enn komin reynsla á en pá vinnu má ekki vinna í fljótfærni heldur með langtímamarkmið að leiðarljósi.

Ég vona að sagan um litlu negrastrákana endi hér og peir verði aftur 10, eða 25 eins og við á í okkar sögu.

What is the cause of crisis in internal medicine?

Ingibjörg Kristjánsdóttir, Resident in internal medicine and Bsc in Internal business and administration. 